\title{
Increased Interest in Science Learning Through Integrated Learning of Local Snacks with The Discovery Learning Model
}

\author{
Wilda Muhimmatun Nisa ${ }^{\mathrm{a}, 1, *}$, Insih Wilujeng ${ }^{\mathrm{b}}$, Diego Pradana ${ }^{\mathrm{b}}$ \\ ${ }^{a}$ Universitas Negeri Yogyakarta - Jl. Colombo No. 1, Daerah Istimewa Yogyakarta, 55281 Indonesia \\ ${ }^{b}$ Universitas Negeri Surabaya - Jl. Unesa IBD Lidah Wetan, Surabaya, 60213 Indonesia \\ ${ }^{1}$ wildaemnisa@gmail.com \\ * corresponding author
}

\begin{abstract}
\begin{tabular}{l|l} 
ARTICLE INFO ABSTRACT & AR
\end{tabular}
Article history

Received September 29, 2020

Revised Dec 16, 2020

Accepted Dec 20, 2020

Keywords

Local Potential

Discovery Learning

Learning Interest

This study aimed to determine the interest in learning science after using integrated learning of local snacks in Cangkringan with the Discovery Learning model at Cangkringan Junior High School 1. This study is a pre-experimental design that used a one-group pretest-posttest design. The sample in this study were 31 students of 7 A-class, 2019/2020 academic year. Data collection techniques used observation and questionnaire of interest in learning before and after treatment to measure student interest in learning. Observations were carried out by investigating activities that are taking place in class. The indicator of learning interest instruments, in the questionnaire is interest, pleasure, attention, and desire or awareness. Learning interest data was generated in the form of scores (quantitative data) with 4 scales, namely strongly agree (SS), agree (S), less agree (KS), and disagree (TS). The questionnaire was developed by researchers by showing indicators of interest in learning with 23 questions. Data analysis techniques used N-Gain analysis techniques and descriptive analysis by converting the results of percentage analysis. The result shows that the students' interest in learning science after implementation of integrated learning of local potential with discovery learning models increases with an $\mathrm{N}$-gain score of 0.59 in the medium category. The average percentage value of descriptive analysis of student learning interest has increased from $72.01 \%$ with moderate criteria to $88.56 \%$ with high criteria.

Penelitian ini bertujuan untuk mengetahui minat belajar IPA setelah menggunakan pembelajaran terintegrasi jajanan lokal daerah Cangkringan dengan model pembelajaran Discovery Learning di SMPN 1 Cangkringan. Jenis penelitian ini adalah eksperimen bentuk pretest-postest pre-eksperimental design. Sampel dalam penelitian ini yaitu siswa kelas VIIIA sebanyak 31 siswa tahun ajaran 2019/2020. Teknik pengumpulan data menggunakan lembar observasi dan angket minat belajar sebelum dan sesudah perlakuan guna mengukur minat belajara siswa. Observasi dilakukan dengan mengadakan pengamatan terhadap kegiatan yang sedang berlangsung di kelas. Indikator minat belajar pada angket adalah rasa tertarik, perasaan senang, perhatian, dan keinginan atau kesadaran. Data minat belajar yang dihasilkan berupa skor (data kuantitatif) dengan skala 4 yaitu sangat setuju (SS), setuju (S), kurang setuju (KS), dan tidak setuju (TS). Angket dikembangkan peneliti dengan memperlihatkan indikator minat belajar dengan 23 pertanyaan. Teknik analisis data menggunakan teknik analisis $N$-Gain dan analisis deskriptif yang dengan cara mengkonversi hasil analisis persentase. Berdasarkan penelitian, minat belajar IPA siswa setelah diterapkan pembelajaran terintegrasi potensi lokal dengan model discovery learning meningkat dengan skor N-gain 0,59 dengan kategori sedang. Rata-rata nilai persentase analisis deskriptif minat belajar siswa mengalami peningkatan dari $72,01 \%$ dengan kriteria sedang menjadi $88,56 \%$ dengan kriteria tinggi.
\end{abstract}

This is an open access article under the CC-BY license.

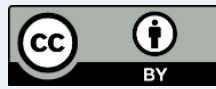

\section{Introduction}

Learning in Curriculum 2013 pays attention to student's active participation through studentcentered learning, which is expected to encourage enthusiasm for learning, motivation, interest, crea- tivity, initiative, inspiration, innovation, and independence (Permendikbud, 2016). Interest is an intrinsic factor that influences student learning outcomes as a positive effect (Kahraman \& Sungur-Vural, 2012). Interest will have an impact on the seriousness of students in learning (Isa, 2012). 
Based on the results of observations made by researchers showed that learning at Junior High School 1 Cangkringan is still teacher-centered so that students have not been actively involved during the science learning process. Facilities in schools are inadequate in the science learning process, as seen from a poorly maintained science laboratory. This has become one of the factors in the lack of student interest in learning. Students feel less challenged in participating in science learning because teachers do not use the environment as a source of learning (Lathifah \& Wilujeng, 2016).

Local potential-based learning as a source of learning contributes positively to students' learning (Agung, 2015; Khoiri et al., 2018). Local potentials can be utilized in learning, both as media and learning resources (Lase, 2016; Mungmachon, 2012). The utilization of local potentials can provide direct experience to students with learning resources around the school (Anisa, 2017). The learning associated with material that is familiar to students is indispensable because it can avoid the difficulties of students (Agustin et al., 2018). Discovery Learning is studentcentered learning, where learning is done through their own experience (Fitriani et al., 2017). Discovery Learning can improve student activity in learning. This has a positive impact on students' interests and learning achievement (Wahjudi, 2015). But according to (A'yun \& Subali2, 2019), students who actively participate appear less because learning is centered only on the teacher.

One of the science materials in Junior High School students is about additives, one of which additives artificial dye and natural dyes. In this research, local snacks that are integrated into learning include Bolu Javanese (red-colored), the hair Sempe (pink), taro crackers (green), and Talas chips (colored yellow). This local hawker is often encountered by SMPN 1 Cangkringan because the food is found in the market near the school, which does not close the possibility that the school cafeteria also sells this snack. This local snack is integrated into the sub material additives about artificial dyes. Students often eat this snack but have never known that what they consume can be scientifically analyzed.

Based on these descriptions through the local snacks with discovery learning models, researchers expect this learning can affect students' learning interests. The implementation of discovery learning in science learning can help students utilize nearby learning resources, including local snacks so that students are more active and passionate about science learning. In connection with this statement, research needs to be conducted to learn about integrated local snacks with the discovery learning model for Junior High School students. This study aims to determine the increase of interest in learning science after using integrated learning of local snacks in Cangkringan with the Discovery Learning model at Cangkringan Junior High School.

\section{Method}

The method used in this study is a preexperimental design that does not include a control group, with a one group pretest-posttest design model. In this study, there was one group given a questionnaire of interest in learning before and after treatment to measure their interest in learning. The indicator of learning interest instruments in the questionnaire is interest, pleasure, attention, and desire, or awareness.

The sample in this study were 31 students of 7 Aclass of Cangkringan junior high school 1, academic year of 2019/2020. Data collection techniques used were observation and questionnaire. Observations were carried out by holding observations of activities in class. Learning interest data was generated in the form of scores (quantitative data) with 4 scales of strongly agree (SS), agree (S), less agree (KS), and disagree (TS). The questionnaire was developed by researchers by showing indicators of interest in learning with 23 questions.

The data analysis technique used was a standard gain score analysis and descriptive analysis by describing it using a percentage formula. The poll Data before and after the treatment calculated the standard gain value by using the gain formula as follows.

Gain score $=\frac{\text { Score after treatment }- \text { score before treatment }}{\text { maximum score-pretest score }}$

The Gain score can be interpreted using the following Table 1.

Table 1. Interpretation of Gain score

\begin{tabular}{cc}
\hline $\mathbf{G}$ & Criteria \\
\hline $\mathrm{g} \geq 0.7$ & High gain \\
$0.3 \leq \mathrm{g}<0.7$ & Medium gain \\
$\mathrm{g}<0.3$ & Low gain \\
\hline
\end{tabular}

The data analysis technique used was descriptive analysis techniques to analyze data by describing the percentage formula as follows.

$$
P=\frac{f}{N} \times 100 \%
$$

Description:

$\mathrm{P}=$ Number of learning interest percentage

$\mathrm{f}=$ Frequency searched

$\mathrm{N}=$ Maximum number of scores

(Kahayun et al., 2015) 
After that, the percentage calculation results were converted qualitatively with the conversion guidelines in the following Table 2.

Table 2. Learning Interest Criteria

\begin{tabular}{cc}
\hline Percentage (\%) & Criteria \\
\hline $76-100$ & High \\
$56-76$ & Medium \\
$0-56$ & Low \\
\hline a. (Suharsimi, 2013)
\end{tabular}

\section{Results and Discussion}

The results of this research on increased natural science learning interest of junior high school students' through integrated learning of local snacks with the discovery learning model are shown in Table 3 .

Table 3. Gain Score of Student Learning Interest

\begin{tabular}{ccccc}
\hline $\begin{array}{c}\text { Indica- } \\
\text { tor }\end{array}$ & $\begin{array}{c}\text { Score } \\
\text { Before } \\
\text { Treat- } \\
\text { ment }\end{array}$ & $\begin{array}{c}\text { Score } \\
\text { After } \\
\text { Treat- } \\
\text { ment }\end{array}$ & $\begin{array}{c}\text { Gain } \\
\text { Scor } \\
\text { e }\end{array}$ & $\begin{array}{c}\text { Crite- } \\
\text { ria }\end{array}$ \\
\hline Interested & 666 & 801 & 0,67 & Medium \\
Pleasure & 255 & 326 & 0,61 & Medium \\
Attention & 523 & 643 & 0,54 & Medium \\
Awarenes & 629 & 765 & 0,57 & Medium \\
s & & & 0,59 & Medium \\
\hline & Mean & & &
\end{tabular}

Table 3 shows that the average student interest in learning has increased from before and after treatment by 0.59 with medium criteria. The biggest increase was seen in the interest indicator by 0.67 with medium criteria. The smallest increase was seen in the attention indicator of 0.54 with medium criteria.

Descriptive analysis of natural science learning interest of junior high school students' through integrated learning of local snacks with the discovery learning model is shown in Table 4. Table 4 shows the details of the increase in each indicator of student learning interest. The indicator of interest has increased in percentage but remains in the high category. While other indicators, including pleasure, attention, and awareness, also experienced an increase of percentage value along with an increase in the criteria, from medium to high. The average percent-age value of descriptive analysis of student learning interest has increased from $72.01 \%$ with medium criteria to $88.56 \%$ with high criteria.

Assessment of student interest in learning is obtained from the results of student questionnaires with 23 questions developed from 4 indicators. The four indicators include attraction, pleasure, attention, and awareness. Table 2 shows students' learning interest score data before and after treatment. Furthermore, the Gain score results are obtained from students' interest scores before and after treatment. Based on the results of the Gain score, the students have increased interest in learning on the four indicators in learning using discovery learning models.

Table 4. Descriptive Analysis of Student Learning Interest

\begin{tabular}{ccccc}
\hline $\begin{array}{c}\text { Indica- } \\
\text { tor }\end{array}$ & $\begin{array}{c}\text { Percent- } \\
\text { age Be- } \\
\text { fore } \\
\text { Treat- } \\
\text { ment }\end{array}$ & $\begin{array}{c}\text { Crite- } \\
\text { ria }\end{array}$ & $\begin{array}{c}\text { Percent- } \\
\text { age Be- } \\
\text { fore } \\
\text { Treat- } \\
\text { ment }\end{array}$ & $\begin{array}{c}\text { Crite- } \\
\text { ria }\end{array}$ \\
\hline $\begin{array}{c}\text { Being } \\
\text { interested } \\
\text { Pleasure }\end{array}$ & 76,73 & High & 92,28 & High \\
$\begin{array}{c}\text { Attention } \\
\text { Awarene }\end{array}$ & 78,55 & Medium & 87,40 & High \\
ss & 72,47 & Medium & 86,42 & High \\
\hline Mean & 72,01 & Medium & 88,13 & High \\
\hline
\end{tabular}

At the stimulation and problem statement stage, local snacks of Bolu Javanese in red was displayed. Then, the students observed the cake to find the problem that could be discussed in the learning according to dye additive material. In the data collection and data courtesan procession stage, students completed a test of additive testing substances in the artificial and natural dyes using local snack materials and some natural indicators for comparators, namely Rosella Flower extract, pandan leaf extract, and turmeric extract. In the verification phase, students answered questions on the LKS that supports learning. At the generalization stage, students with teachers concluded differences in natural dye additives and artificial dyes in accordance with the experiment that had been carried by the students. This is consistent with the opinion of (Sopiah \& Sangadji, 2019), which states that the teacher must carry out a pleasant learning process that not only focuses on teaching, but students must also work directly in solving problems. In addition, learning materials are also enhanced to suit current developments by offering the skills needed in the $21^{\text {st }}$ century (Anggraeni, 2019).

When learning takes place by using discovery learning with examples of local snacks, students are active in participating in learning by asking questions to the teacher or discussion partners. This is because the sample objects used in learning are close to the student environment, so students are more interested in learning them, even wanting to try other local snacks. This is because students are directly involved in learning and observing objects close to their environment. This statement is following research (Maulidar et al., 2016), which states that Discovery learning has a positive impact on students because 
they have the opportunity to be more active during learning. Also supported by (Salwan \& Rahmatan, 2018; Wahjudi, 2015) that discovery learning has a positive impact on student interest and learning outcomes. Discovery learning can increase student activity in learning individually or in groups (Wahjudi, 2015). The discovery learning id also in accordance with the integration of local potential that can provide direct experience to students with learning resources that are around the school (Anisa, 2017)). Increasing student activity in learning makes students more enthusiastic in learning and will increase student interest in learning. Discovery learning is also in accordance with the integration of local potential that can provide direct experience to students with learning resources that are around the school (Wahjudi, 2015). Increasing student activity in learning makes students more enthusiastic in learning and will increase student interest in learning. Discovery learning is also in accordance with the integration of local potential that can provide direct experience to students with learning resources that are around the school (Anisa, 2017). Increasing student activity in learning makes students more enthusiastic in learning and will increase student interest in learning"

\section{Conclusion}

Based on the results of the data analysis and discussion, it can be concluded that the students' interest in learning science after the implementation of integrated local potential learning with discovery learning models increases with an $\mathrm{N}$-gain score of 0.59 in the medium criteria. The average percentage value of descriptive analysis of student learning interest has increased from $72.01 \%$ with medium criteria to $88.56 \%$ with high criteria. Based on the research that has been done, the local wisdom around the school can be incorporated with various learning models so that students' interests and abilities develop more while participating in learning.

\section{References}

A'yun, S. N., \& Subali, B. (2019). Sifat-sifat cahaya dalam Discovery Learning untuk meningkatkan keterampilan proses sains. Jurnal Ilmu Pendidikan, 24(2), 75. https://doi.org/10.17977/um048v24i2p75-79

Agung, L. S. (2015). The development of local wisdombased social science learning model with Bengawan Solo as the learning source. American International Journal of Social Science, 4(4), 51-58.

Agustin, P. U. W., Wahyuni, S., \& Bachtiar, R. W. (2018). Pengembangan modul Fisika berbasis potensi lokal "batik lumbung dan tahu tanaman" untuk siswa SMA di Kecamatan Tamanan Bonndowoso (materi suhu dan kalor). Jurnal Pembelajaran Fisika, 7(1), 62-69. https://doi.org/https://doi.org/10.19184/jpf.v7i1.7218
Anggraeni, A. D. (2019). Blended humor and mind mapping in improving 21st century skills. Jurnal Ilmu Pendidikan, 25(1), 1-5.

Anisa, A. (2017). Meningkatkan keterampilan berpikir kritis peserta didik melalui pembelajaran IPA berbasis potensi lokal Jepara. Jurnal Inovasi Pendidikan IPA, 3(1), 1-11. https://doi.org/10.21831/jipi.v3i1.8607

Fitriani, U., Karyadi, B., \& Ansori, I. (2017). Penerapan Model Discovery Learning untuk meningkatkan pemahaman konsep biologi siswa SMP. Diklabio: Jurnal Pendidikan Dan Pembelajaran Biologi, 1(1), 82-90. https://doi.org/10.33369/diklabio.1.1.$82-90$

Isa, A. (2012). Keefektifan pembelajaran berbantuan multimedia menggunakan metode inkuiri terbimbing untuk meningkatkan minat dan pemahaman siswa. Jurnal Pendidikan Fisika Indonesia, 6(1), 1-1. https://doi.org/10.15294/jpfi.v6i1.1105

Kahayun, K., Wakidi, W., \& Ekwandari, Y. S. (2015). Pengaruh Gallery Walk terhadap minat belajar sejarah di SMAN 1 Natar. Jurnal Pendidikan Dan Penelitian Sejarah, 5(2).

Kahraman, N., \& Sungur-Vural, S. (2012). An investigation on students' personal achievement goals and perceived parents' goal emphases in science. Asia-Pacific Forum on Science Learning and Teaching, 13(2), 1-19.

Khoiri, A., Syifa, A., \& Mubin, N. (2018). Potential local physics-based learning of Jepara district to improve science process skills and students entrepreneurship. Formatif: Jurnal Ilmiah Pendidikan MIPA, 8(1), 57-68. https://doi.org/10.30998/formatif.v8i1.2365

Lase, N. K. (2016). Pengembangan Lembar Kegiatan Siswa (LKS) berbasis potensi lokal pada mata pelajaran Biologi SMA kelas XII. Jurnal Pendidikan Biologi, 5(2), 99-107. https://doi.org/10.24114/jpb.v5i2.4305

Lathifah, I. N., \& Wilujeng, I. (2016). Pengembangan perangkat pembelajaran integrated science berbasis kearifan lokal. Jurnal Pendidikan Matematika Dan Sains, 4(2), 110-119. https://doi.org/10.21831/jpms.v4i2.12920

Maulidar, N., Yusrizal, Y., \& Halim, A. (2016). Pengaruh penerepan model pembelajaran Guided Discovery terhadap kemampuan pemahaman konsep dan ketrampilan berpikir kritis siswa SMP pada materi kemagnetan. Jurnal Pendidikan Sains Indonesia, 4(2), 69-75.

Mungmachon, M. R. (2012). Knowledge and local wisdom: Community treasure. International Journal of Humanities and Social Science, 2(13), 174 181.

Permendikbud. (2016). Permendikbud Nomor 21 Tahun 2016 tentang standar isi pendidikan dasar dan menengah (Issue May). Kementerian Pendidikan dan Kebudayaan RI. 
Salwan, S., \& Rahmatan, H. (2018). Pengaruh LKPD berbasis discovery learningterhadap peningkatan hasil belajar siswa. Jurnal Pendidikan Sains Indonesia, 5(2), 25-31. https://doi.org/10.24815/jpsi.v5i2.9812

Sopiah, S., \& Sangadji, E. M. (2019). The effect of lecturer commitment on student academic achievement toward student satisfaction through perceived teaching quality. Jurnal Ilmu Pendidikan, 25(2), $50-57$.
Suharsimi, A. (2013). Prosedur penelitian suatu pendekatan praktik. Rineka Cipta.

Wahjudi, E. (2015). Penerapan Discovery Learning dalam pembelajaran IPA sebagai upaya untuk meningkatkan hasil belajar siswa kelas IX-I. Jurnal Lentera Sains (Lensa), 5(1), 1-16. https://doi.org/10.17509/EH.V7I2.2705.G1760 